DOI: https://doi.org/10.18371/fp.4(36).2019.190231

УДК 658: 330

\title{
ФРАНЧАЙЗИНГ ЯК ЕФЕКТИВНА ФОРМА ПАРТНЕРСТВА ІЗ ЗАКОРДОННИМИ ФІРМАМИ
}

\author{
ЛИТВИН Олена Євгенівна \\ к.е.н., доцент кафедри економіки та менеджменту \\ Інституту банківських технологій та бізнесу \\ ДВНЗ «Університет банківської справи» \\ e-mail: kafedra_mm@ukr.net
}

\section{ЗАПОРОЖЕЦЬ Марина Олегівна}

магістрант Інституту банківських технологій та бізнесу

ДВНЗ «Університет банківської справи»

e-mail: marina9364@gmail.com

Анотація. $y$ статті визначено суть франчайзингу. Розглянуто стан франчайзингу в Україні та закордоном. Описано можливі порушення франчайзера та франчайзі на переддоговірному та постдоговірному етапах. Розглянуті фактори становлення франчайзингових відносин $y$ сфрері бізнесу великих і малих фрірм на базі аналізу закордонного досвіду франчайзингу. Окреслюється франчайзинг як зовнішньоекономічне партнерство.

Ключові слова. прочес глобалізачії, франчайзинг, франшиза, франчайзер, франчайзі, форми франчайзингу.

Постановка проблеми. Сучасний стан економіки, іiі інтернаціоналізація обумовлюють необхідність розробки організаційно-економічних основ формування інтегрованих форм бізнесу, а основними причинами відмови від створення власного бізнесу $є$ недостатність коштів для відкриття власної справи, нестабільність економіки країни, нестача досвіду у здійсненні підприємницької діяльності. Дієвим
Аннотация. $B$ cmamье определена суть франчайзинга. Рассмотрено состояние франчайзинга в Украине и за рубежом. Описаны возможные нарушения франчайзера и франчайзи на преддоговорном $и$ постдоговирному этапах. Рассмотрень факторы становления франчайзинговых отнотений в сфере бизнеса крупных и мальх фирм на основе анализа зарубежного опьта франчайзинга. Определяется франчайзинг как внешне-экономическом партнерстве.

Ключевые слова. прочесс глобализаџии, франчайзинг, франшиза, франчайзер, франчайзи, формы франчайзинга.

інструментом, який дозволяє вирішити дану ситуацію, $є$ франчайзинг. Світова практика свідчить, що франчайзинг - один 3 ефективних способів розвитку бізнесу фірм, що вже добилися успіху та бажають розвивати свій успіх і надалі. 3 іншого боку, франчайзинг - це найкраща можливість організувати надійну власну справу для дрібного підприємця. Нині франчайзинг отримав надзвичайну попу- 
лярність у розвинених країнах. Це зумовлює актуальність висвітлення основних аспектів використання франчайзингу та перспективи розвитку даної форми бізнесу для України.

Аналіз останніх досліджень та публікацій. Вивченням питань франчайзингу займались вітчизняні та іноземні науковці, такі як: Джон Вон Ейкен, Скотт А.Шейн, Ян Мюрей, 3.С.Варналій, О.В.Гладка, І.В.Кононов, О.С.Кузьмін, В.Ю.Мавріду, С.А. Сосна, А.В.Цірат, Дельтей Ж., Котлер Ф., Ламбен Ж., Мендельсон М. Дані автори розглядали законодавче регулювання, договірний процес, правове регулювання франчайзингу, складності процесу франчайзингу, а також описали реалії франчайзингу із середини підприємств франчайзера та франчайзі.

Метою статті $є$ розкриття сутті франчайзингу, порівняння стану франчайзингу в Україні та країнах ЄC, дослідження особливостей розвитку франчайзингу в світі та визначення перспектив використання такої форми ведення бізнесу в Україні, а також визначення питання щодо успішного розвитку даного проекту та розгляд франчайзингу, як ефективної форми партнерства із закордонними фірмами.

\section{Виклад}

основного

мaтеріалу. Франчайзинг - це система договірних, взаємовигідних відносин на платній основі, згідно яких одна сторона (франчайзер) безстроково або ж на певний строк передає іншій стороні (франчайзі) право на використання об'єкту інтелектуальної власності, та надає консультаційну чи технічну допомогу у виробництві та реалізації продукції, виконанні робіт і наданні послуг. Якщо це «договірні відносини», то безумовно, що першим кроком має бути укладання договору франчайзингу. Правовою особливістю франчайзингу в Україні $\epsilon$ те, що в національному законодавстві не передбачено договору 3 такою назвою. Але це не $є$ перешкодою провадження діяльності, оскільки в ЦК України [1] передбачений договір комерційної концесії, який за суттю повністю відповідає франчайзингу. На думку А.В.Цірат [2] законодавство вводить в оману суспільство, називаючи договір франчайзингу договором комерційної концесії. Предметом договору є право на використання об'єктів інтелектуальної власності. «Взаємовигідні відносини» означають, що договір укладається між не пов'язаними між собою особами (як фізичними, так i юридичними), які через певний час очікують отримати користь у грошовому виразі. Відповідно до договору, франчайзер надає франчайзі виняткове право (франшизу) на використання торгової марки для заняття певним видом бізнесу на певній території i протягом певного проміжку часу за умови суворого дотримання вимог франчайзера щодо ведення бізнесу. «Платна основа» передбачає, що за користування торговою маркою франчайзі сплачує франчайзеру роялті, яка може бути оплачена різними схемами [3].

Франшиза - це спеціальний пакет документів, який включає право користування торговою маркою. Дані терміни відрізняються за своєю сутністю, але тісно пов'язані між собою. Об'єкт інтелектуальної власності $\epsilon$ центром уваги суб'єктів, які викори- 
стовують його у своїй діяльності з ме- номічних вигід; основою такого протою отримання майбутніх еко- цесу є договірні відносини (Рис.1) [4]

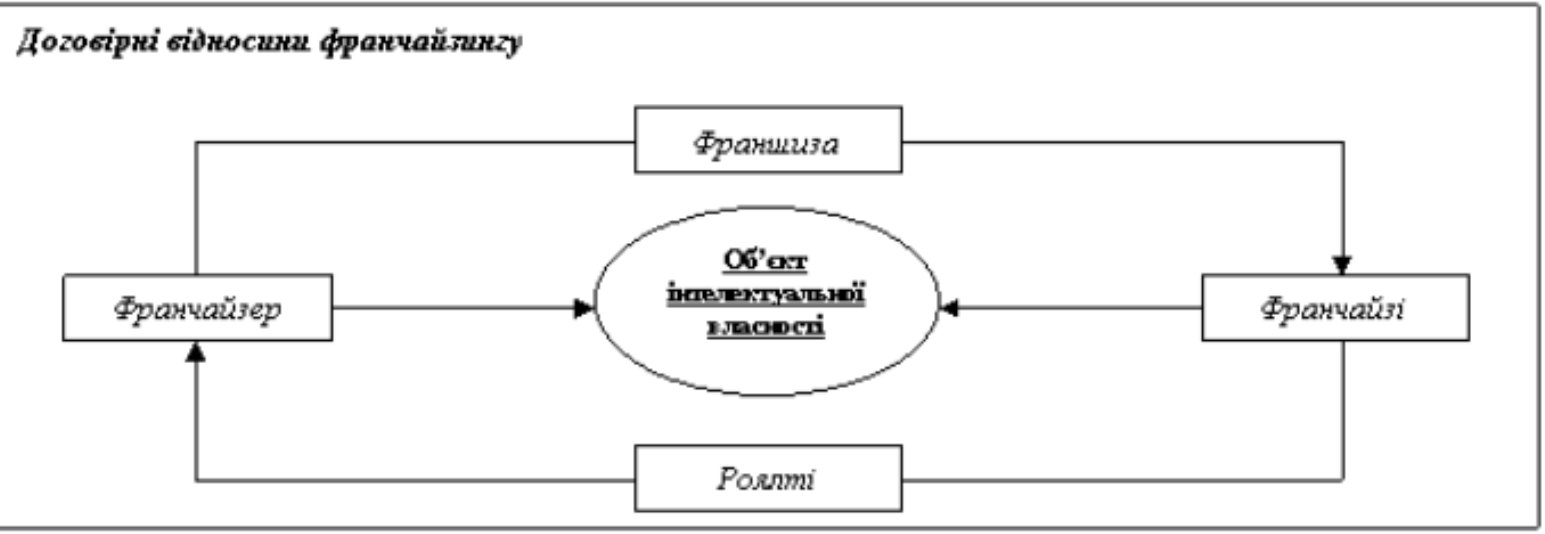

Рис. 1. Процес організації франчайзингу

Для компаній франчайзинг - це спосіб поширення бізнесу. Для підприємців франчайзинг - це один 3 шляхів стати власником бізнесу. На зростаючих ринках, таких як Україна, франчайзинг $\epsilon$ швидким способом навчання підприємців практичним стандартам, що необхідні, щоб вести прибутковий бізнес.

Франчайзинг - свого роду симбіоз «великого» і «малого» бізнесу. Таке з'єднання являє собою союз, де з однієї сторони є енергія і зобов'язання окремого підприємця, а з іншої сторони $є$ ресурси, комерційна міць і величезний досвід великої компанії.

Франчайзер (франшизіар) - це компанія, що видає ліцензію або передає в право користування свій товарний знак, ноу-хау й операційні системи. Франчайзер створює успішний продукт чи послуги, наприклад, особливий стиль роботи ресторану швидкого харчування. Франчайзер досліджує, i розвиває бізнес, витрачає гроші на просування бізнесу, створює гарну репутацію і пізнаваний імідж (так званий «бренднейм»). Після того, як ком- панія довела працездатність своєї бізнес концепції й успішну відтворюваність цього бізнесу, вона може почати пропонувати підприємцям, що хочуть повторити подібний успіх, купити іiі франшизу.

Франчайзі (франшизіат) - це людина або компанія, що купує у франчайзера можливість навчання і отримання допомоги при створенні бізнесу i виплачує сервісну плату (роялті) за використання товарного знаку, ноухау і системи ведення робіт франчайзера. Франчайзі сам оплачує витрати на створення бізнесу. Дуже часто франчайзер надає дуже вигідні знижки на важливі постачання (матеріали, видаткові кошти). Ці знижки завжди дають можливість франчайзі купувати продукти у франчайзера по більш вигідній ціні й у такий спосіб це коштує дешевше, ніж розвивати бізнес без франчайзера. Франчайзі робить первісний внесок за допомогу по створенню і відкриттю бізнесу. Франчайзі приймає на себе обов'язок виплачувати щомісячні внески за право користування торговим знаком i 
бізнес системою, за підтримку, навчання i консалтінг, що надаються франчайзером.

Франшиза - це повна бізнес система, яку франчайзер продає франчайзі. Іншою назвою для подібної системи служить франчайзінговий пакет, що зазвичай включає посібники по веденню робіт і інші важливі матеріали, що належать франчайзеру.

Більшість науковців вважають, що франчайзинг зародився у США. Наприкінці XIX століття, коли ряд великих компаній США продають малому бізнесу право на продаж своїх виробів по всій країні, він досягає розквіту.

Початківцем в освоєнні франчайзингу вважають компанію «Зінгер» Спонукала до цього її власника нестача грошових засобів для наймання комівояжерів, оскільки на той час купівля-продаж відбувалася у покупця вдома після наочної демонстрації властивостей товару. Щоб не зменшувати обсяг виробництва, компанія вирішила продати право на реалізацію швейних машин незалежним продавцям на певній території.

Інша молода компанія «Дженерал моторс» також у 1898 р. створила ефективну франчайзингову систему. Не маючи засобів для відкриття власної мережі магазинів, вона продавала парові двигуни через дилерів, таким чином запроваджуючи початок сучасної системи продажу автомобілів.

Дилеру виділялася певна територія і гарантувався захист від конкурентів Натомість він брав на себе зобов'язання не продавати машини інших виробників, забезпечувати високий рівень обслуговування і підтримувати імідж компанії. У такий же спосіб компанією «Рексол» було організовано мережу аптек.

3 початку 1930-х років франчайзинг став основним напрямком розвитку ресторанів фаст-фуд, зокрема таких компаній, як McDonald's, Kentucky Fried Chicken, Dairy Queen i Hardee's, компаній Pepsi i 7-UP. Після «великої депресії» у США нафтопереробні компанії почали використовувати джоббінг - своєрідний аналог франчайзингу. У $60-70$ роках $\mathrm{XX}$ сторіччя в США почався дійсний бум франчайзингу в розвитку малого i ceреднього бізнесу. У країні відкривалася величезна кількість турагентств, готелів, хімчисток, пралень, СТО, салонів краси, ресторанів, кафе, розважальних клубів і т.п. [5, с. 36-40].

На початку XX ст. була запроваджена нова форма організації франчайзингу між оптовими i роздрібними торговцями. У Великобританії в основу організації системи бакалійних магазинів - «Ві-Джі гроусері сторс» було закладено принцип інвестування власником малого бізнесу нематеріальними активами.

У США згідно $з$ дослідженням, проведеним «Naisbitt Group» у 2009 р., галузеві експерти прогнозували, що продаж через франчайзингову систему досягне 438 млрд. USD у 2010 р. та 705 млрд. USD у 2011 р. До 2012 р. продажі мали досягти 1 трлн. USD та 1,3 трлн. USD у 2013 р. відповідно [5]. Причинами тривалого зростання франчайзингу в США за припущеннями фахівців є зростання особистого доходу, стабільність цін, високий рівень оптимізму споживачів і вища конкуренція за частину ринку. Без- 
умовно, також важливим чинником, що зробив внесок у розвиток франчайзингу, стала привабливість США для іноземних компаній. Особливо активно з'являлися на ринку США канадські, європейські та японські франчайзери зі своїми системами, що вже досягли успіху в цих країнах. Так, у 2009 р. в США вже працювало 60 іноземних франчайзерів. Французька фірма "Пронуптіа" (Pronuptia), що спеціалізується на весільних вбраннях, англійські фірми "Уімпіз" (Wimpys) i "Бейк Ен Тейк" (Bake N Take), німецька "Вінервальд" (Wienerwald), що займається продуктами харчування, були у США серед перших i найуспішніших у цій галузі.

Американські франчайзери досягли значного успіху в іноземних країнах: "Бургер Кінг" (Burger King ), "Хардіз" (Hardees), "Холідей Ін" (Holiday Inn), "Ховард Джонсонс" (Howard Johnsons), "Баскін-Робінс" (BaskinRobbins), "Мейнеке Діскаунт Мафлерс" (Meineke Discount Mufflers), "Грейт Америкен Куки" (Great American Cookie) — це американські франшизи, куплені неамериканськими фірмами [6].

В основі поширення популярності франчайзингу є наступні чинники:

1) купуючи бізнес, франчайзі отримує майже абсолютну підтримку 3 боку франчайзера - напрацьовані технологіï, рекламу, бренд і низку послуг, які надаються відповідно до умов певної франшизи. Франчайзі отримує інформацію, що допомагає знайти місце розташування підприємства, сформувати його стиль і забезпечити та проконтролювати функціонування. Завдяки отриманим уже основам, що здобув франчайзер, покупець знижує ризик провалу на початковій стадії свого проекту;

2) франчайзеру така угода дає інвестиції, необхідні для розвитку, регіони для роботи через поширення бренду, а також створює стійкий ринок із певними складностями для конкурентів [7].

Згідно зі статистичними даними Міжнародної асоціації франчайзингу, середня рентабельність інвестицій за перші 10 років роботи для звичайних незалежних підприємств становить близько 300\%. Для компаній, які працюють у межах франшизи, - 600\%.

Iз усіх створюваних у світі незалежних компаній на протязі трьох років у середньому близько 90\% закінчують своє існування, тоді як для франчайзингових компаній частка банкрутів у перші три роки становить менше 10\% [8]. За даними вітчизняної статистики, 77\% усіх підприємств в Україні припиняють свою діяльність після семи років роботи на ринку, після 10 років тільки 18\% продовжують працювати, тоді як тільки 8\% підприємств, які працюють за договором франчайзингу, залишають ринок через П'ять років роботи і 90\% утримують свої позиції після 10 років існування на ринку [9].

Найбільше франчайзингові відносини й досі розвинені у США і застосовуються як мінімум у 65 сферах: готельному та туристичному бізнесі, громадському харчуванні, автосервісі та оренди машин, постачанні в різних галузях (служба логістичних послуг), будівництві, мережі хімчисток, салонах краси, продажу товарів по каталогах, медичних, страхових, бухгалтер- 
ських (аудиторських), фінансових послугах, фармацевтиці, оптиці, торгівлі тощо. У Великобританії на основі франшизи працюють у 46 сферах бізнесу, з яких виділяють 38 додаткових секторів [10]. В Україні лідерами у сфері франчайзингового бізнесу $\epsilon$ підприємства роздрібної торгівлі товарами і послугами, ресторани швидкого харчування і бізнес-послуги. У 2016 р. сфера роздрібної торгівлі товарами і послугами, що розвивається за франчайзингом, становить $34 \%$ від загальної кількості франчайзингових підприємств [11].

Аналізуючи досвід країн з високорозвиненою економікою, можна стверджувати, що франчайзинг $\epsilon$ дієвим інструментом, що забезпечує розвиток малого і середнього бізнесу, а це, в свою чергу, позитивно впливає на розвиток економіки країни загалом. Серед європейських країн лідируючі позиції завдяки розповсюдженню франчайзингу займає Франція (45\% всього європейського франчайзингового ринку) - понад 1900 франчайзерів і 71508 франчайзі, річний оборот становить 55,1 млрд євро [10]. Особливістю французького франчайзингового ринку $\epsilon$ те, що він не $\epsilon$ привабливим для виходу на нього іноземних франчайзингових систем, оскільки у Франції встановлюють трудомісткий порядок оформлення франшиз.

Ситуація на ринку Німеччини сприяє розвитку іноземних франшиз, де в 2016 р. налічується 1300 франчайзингових мереж i 118000 франчайзі, річний оборот 92 млрд. євро і більше ніж 686000 зайнятих фахівців. Такі французькі бренди, такі як: Yves Rocher, Kookai, Promod, Pimkie вже довгий час розвиваються на німецькому ринку. У відсотковому співвідношенні $50 \%$ всього ринку франчайзингу Німеччини займають послуги, 21\% ресторани і готелі, $29 \%$ займає торгівля. Великобританія займає в Європі 3 місце за кількістю франчайзингових мереж. Там налічується приблизно 1089 франчайзерів і 44200 франчайзі з річним обсягом продажів в 17,2 млрд євро, і більш 621000 зайнятих фахівців [11]. Перші підприємства на умовах франчайзингу в Україні почали працювати в 1993 р. у рамках міжнародної інформаційної системи «Компас» (Нідерланди). Як результат у 1999 р. у Києві було відкрито перше вітчизняне франчайзингове підприємство ресторанного господарства - піцерію Pizza Celentano [12].

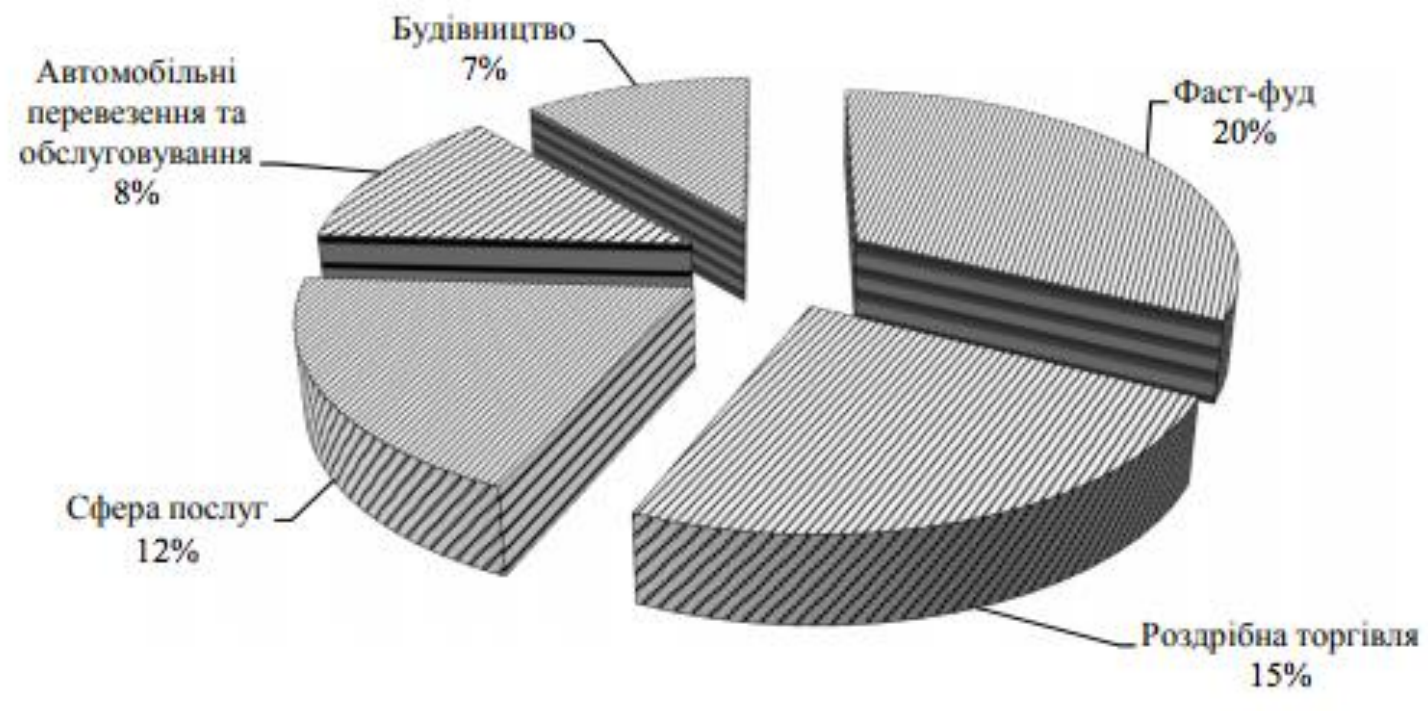


Наразі найбільшим та найрозвиненішим ринком франшиз є США. Американські франчайзери не лише успішно працюють всередині країни, але й завоювали глобальні ринки. Це дозволяє їм водночас отримувати прибутки і задавати тренди світовій індустрії. Згідно рейтингу профільного видання "Franchise Direct" [14], до першої десятки рейтингу Топ-100 франшиз світу потрапили одразу дев'ять американських компаній, які вже другий рік поспіль ділять між собою гравці ринку фастфуду. Так, лідером рейтингу стала компанія McDonald's, яка продає франшизи з 1955 р. Станом на початок цього року компанія має понад 37 тис. точок по всьому світу. На другому місці опинилася мережа ресторанів швидкого обслуговування Burger King, на третьому — Pizza Hut. Найстарішими франчайзерами рейтингу визнані ресторани A\&W та компанія оренди авто Hertz, які продають франшизи вже майже століття - 3 1925 р. Взагалі ж середній “вік” учасників списку - 41,7 року. Як зауважують автори рейтингу, успішність "харчових" франшиз цілком закономірна, адже такі підприємства відносно легко адаптуються та мають доступну для більшості підприємців вартість.

Дещо інакше виглядає список франшиз, що демонструють найшвидші темпи зростання. За версією видання “Entrepreneur"[15], першою за рівнем масштабування $\epsilon$ американська мережа Dunkin' Donuts, заснована 1950 р. Зараз заклади компанії працюють у більш ніж 32 країнах. При цьому за останній рік франчайзер розширився на 409 точок, або ж на 3,4\%, а приріст за останніх три роки склав $12,3 \%$. На другому та третьому місцях опинилися мережа супермаркетів 7-Eleven, що працює 3 1927 р., та фітнесцентри Planet Fitness, засновані 1992 р. До речі, 7-Eleven одночасно вважається найбільшим світовим франчайзером, адже має понад 62,1 тис. магазинів по всьому світу.

Так чи інакше, ринок франшиз у США розвивається досить впевнено, випереджаючи темпи зростання національної економіки. За даними статистичного порталу Statista, торік у країні працювали понад 745,3 тис. франчайзингових точок. Згідно з оглядом 2018 Franchise Business Outlook [16], опублікованим Міжнародною асоціацією франчайзингу (IFA), індустрія розширюється вже восьмий рік поспіль. При цьому одним з позитивних факторів, що сприяє цьому росту, автори огляду називають нещодавню податкову реформу. Загалом, експерти IFA прогнозують, що за результатами поточного року кількість франчайзингових точок на американському ринку збільшиться до 759 тис., або на 1,9\%. Водночас продуктивність франчайзингового бізнесу у фінансовому вираженні має збільшитися на $6,2 \%$ до $\$ 757$ млрд. Франчайзингова індустрія впливатиме й на економічну ситуацію. Очікується, що цьогоріч у галузі будуть зайняті 8,1 млн працівників, що на 3,7\% більше, ніж роком раніше. Також експерти IFA підрахували, що валовий внутрішній продукт одного лише франчайзингового сектора виросте до \$451 млрд i складатиме близько 3\% ВВП США. 
Більшість експертів приходять до висновку, що заклади громадського харчування й надалі гратимуть важливу роль у благополуччі франчайзингового ринку. Проте це не єдина перспективна сфера. Наприклад, американська компанія Sageworks у своєму дослідженні визначила цілий перелік привабливих для франчайзі напрямків 3 найвищою прибутковістю. До нього крім фаст-фудів та ресторанів потрапили сфера нерухомості, готельний бізнес, салони краси та клінінгові компанії. Ще одне дослідження, проведене компанією Неха Research, свідчить про те, що найближчим часом добре розвиватимуться й “кавові" франшизи. Аналітики стверджують, що кава $\epsilon$ найпопулярнішим напоєм, який вживають близько $80 \%$ американців. Тому, враховуючи підвищення попиту на цей продукт, очікується, що до 2025 р. американський ринок “кавових" франшиз зросте до $\$ 13,96$ млрд.

Актуальність використання франчайзингу, як інноваційної форми організації підприємництва в Україні, пов'язана 3 тим, що процес становлення та розвитку бізнесу відбувається в умовах різкого дефіциту фінансових ресурсів, а також відсутності діючої системи фінансування, кредитування й страхування підприємницької діяльності. Характер функціонування франчайзингу в інноваційному механізмі свідчить про те, що на його основі створюються такі форми економічних відносин i зв'язків між суб'єктами господарювання, які внаслідок своєї адекватності природі інноваційного виробництва максимально сприяють його ефективності [10].
Однією з особливостей франчайзингу в цьому випадку виступає сполучення в ньому переваг лізингу та кредиту одночасно, при цьому франчайзинг дозволяє мінімізувати стратегічний ризик для франчайзі (у порівнянні: свій бізнес згортають більше $25 \%$ звичайних малих підприємств і тільки 5\% франчайзі) і надає можливість прискорити торгівельне розширення франчайзера [11].

Франчайзинг сприяє підвищенню інноваційності підприємництва, шляхом прямого або опосередкованого впливу на наступні зовнішні фактори: збалансованість, рівноваги в співвідношенні попиту та пропозиції на інноваційні продукти й послуги 3 обсягу, структури і якості; тривалість годинного інноваційного інтервалу між виникненням, вдосконаленням i впровадженням нових технологій; розробка та проектування нових зразків інноваційної продукції; розвиток соціокультурних чинників (зміна системи цінностей, рівня професійної підготовки, стимулювання працівників); посилення конкуренції, що активізує пошук поліпшення якісних характеристик продукції, відновлення асортиментів; зростання та ускладнення вимог споживачів.

Для ефективного розвитку франчайзингу в Україні як інструменту підвищення інноваційності підприємництва необхідно внести зміни до законодавства, прийняти закон про франчайзинг, а також створити відповідний інноваційний клімат, що сприяє одержанню необхідних знань для ведення бізнесу за франшизою. Франчайзинг, як організаційна форма ведення бізнесу, сприяє інноваційному 
розвитку українських підприємств, оскільки крім торгівельної марки франчайзі здобуває за певну винагороду, нові технології, знання, досвід, імідж франчайзера. Така форма ведення бізнесу дозволяє новим рішенням 3 мінімальними затримками пробиватися на європейські ринки $[17,18]$, надає при цьому підприємцям можливість отримати максимальний прибуток від профінансованого проекту.

Висновки. Аналіз зарубіжного досвіду франчайзингових відносин свідчить про їх високу ефективність та дієвість. Життєдайність фірм, що діють на базі франчайзингу, спонукає до його розповсюдження в багатьох країнах світу, зокрема i в постсоціалістичних країнах. Франчайзинг в своєму розвитку пройшов декілька етапів, набуваючи тих чи інших ознак, модифікаційних форм.

Незважаючи на те, що для України поняття франчайзингу є порівняно новим, останніми роками спостерігається значне його зростання. 3'являються нові вітчизняні франчайзери, а також закордонні компанії виходять на український ринок. Враховуючи всі недоліки українського ринку франчайзингу, його розвиток відбувається повільніше, ніж у країнах СС та США. Проте за сучасних кризових умов даний вид бізнесу залишається одним із найперспективніших та найменш ризиковим для українських підприємців, а також дає можливість підвищити конкурентоспроможність вітчизняної економіки і сприяє виходу країни 3 кризи.

Тим не менш, активне використання франчайзингу в Україні вимагає насамперед реформування законодавчої бази. Але, франчайзинг - це ефективна форма партнерства як із закордонними фірмами, так і з вітчизняними. Франчайзинг створює певні вигоди не лише для власників бізнесу, але й для споживачів. Вони отримують доступ до вітчизняних та імпортних товарів та послуг відомих торгових марок, якість яких перевірена досвідом і часом.

\section{Список використаної літератури}

1. Цивільний кодекс України. URL: http://zakon4.rada.gov.ua/laws/show/43515.

2. Ц Цірат А.В. Франчайзинг та франчайзинговий договір: навч.-практ. посібник/Київ. 2002. 98 с.

3. Бухгалтерський облік договору франчайзингу. Дебет-Кредит. 2014. №30.

4. Облік франчайзингу.Дебет-Кредит. 2013. №16.

5. Ткаченко Я. Франчайзинг як специфічна форма підприємницької діяльності: ретроспективний погляд. Вісник КНТЕУ. 2003. № 6 (спецвипуск). С. 35 40 .

6. Франчайзинг: мировой опыт торговли. URL: http://www.bitrixsoft.ru. 
7. International franchise E-handbook. URL:

http://www.franchiseek.com/Franchise_Directory.htm.

8. Франшиза в туризмі. URL: http://www.businessinvestor.info/journal/article67.htm.

9. Звіт «Франшизи в Україні стійкі до кризи». 2014. URL: http://franchisegroup.com.ua.

10. Les chiffres-clés en France. French Franchise Federation. 2016. URL: http://www.franchise-fff.com/franchise/les-chiffres-cles.

11. Franchise Industry Research. British Franchise Association. 2016. URL: http: //www.thebfa.org/about-franchising/franchising-industry -research.

12. Дончак Л., Гайдей М. Проблеми та перспективи розвитку франчайзингу в Україні. Економічні науки. 2014. URL: http://nauka.Kushnir.mk.ua.

13. Ляшенко В.И., Толмачова А.Ф. Франчайзинг - инструмент предотвращения банкротства малых предприятий. Проблемы формирования антикризисной политики и механизма банкротства предприятий: сб. науч. тр. Донецк: ИЭП НАН Украины. 1998. С. 293-296.

14. ТОП-100 франшиз світу. 2019. URL:https://www.franchisedirect.com/.

15. Franchise 500: Our Definitive Ranking of 2020's Strongest Franchises - 2020. URL: https://www.entrepreneur.com/article/344458.
16. 2018
Franchise
Business
Outlook.
URL: https://www.franchise.org/sites/default/files/Franchise_Business_Outlook_Jan_2018. pdf.

17. Lytvyn, O. (2016). Export potential and opportunities of Ukrainian small and medium enterprises in the European market. Aktualni problemy mizhnarodnykh vidnosyn. - Actual problems of international relations, 127, Vo.2, 165-175 [in Ukrainian].

18. Lytvyn, O. (2016). Foreign trade activity of Ukraine within the framework of signing "FTA+" with the EU countries and FTA with the CIS. Aktualni problemy mizhnarodnykh vidnosyn. - Actual problems of international relations, 127, Vo.1, 116-127 [in Ukrainian]. 